\title{
PENERAPAN POLA HIDUP BERSIH DAN SEHAT UNTUK MENINGKATKAN IMUNITAS TUBUH DI DESA KALIRANCANG,ALIAN, KEBUMEN
}

\author{
Oleh: \\ Yuni Kartika ${ }^{1}$, Farida Pramestian², Nahdiah Masayu ${ }^{3}$, Fathurrohmah Hasanah4, Febri Fera ${ }^{5}$, Ridwan Arifin ${ }^{6}$ \\ Jurusan Biologi, Universitas Negeri Semarang \\ yunikartika967@gmail.com
}

\begin{abstract}
Abstrak
Pola hidup bersih dan sehat (PHBS) adalah sekumpulan perilaku yang dipraktekkan atas dasar kesadaran sebagai hasil pembelajaran yang menjadikan seseorang, keluarga, kelompok atau masyarakat mampu menolong dirinya sendiri (mandiri) di bidang kesehatan dan berperan aktif dalam mewujudkan kesehatan masyarakat. Kelompok mahasiswa KKN BMC UNNES 2020 memiliki misi untuk menjadikan masyarakat Desa Kalirancang, Kecamatan Alian, Kabupaten Kebumen, Jawa Tengah menyadari akan pentingnya menerapkan pola hidup bersih dan sehat (PHBS) dalam kehidupan sehari-hari khususnya dalam masa pandemi Covid-19. Metode pelaksanaan program KKN ini meliputi sosialisasi dan penyuluhan penerapan pola hidup bersih dan sehat (PHBS) secara langsung kepada masyarakat Desa Kalirancang, Kecamatan Alian yang dijadikan objek. Beberapa kegiatan yang dilakukan diantaranya menimbang bayi setiap bulan, menggunakan air bersih, mencuci tangan menggunakan sabun, pola makan yang sehat, dan melakukan aktivitas tubuh. Hasil yang dicapai melalui beberapa kegiatan tersebut yaitu mampu menyadarkan masyarakat akan pentingnya menerapkan pola hidup bersih dan sehat (PHBS) serta dapat memberi pengetahuan kepada masyarakat terkait bagaimana menerapkan pola hidup bersih dan sehat secara tepat sehingga masyarakat dapat menerapkan PHBS secara rutin dalam kehidupan sehari-hari.
\end{abstract}

Kata Kunci: pola hidup bersih dan sehat (PHBS), Desa Kalirancang, sosialisasi

\section{Abstract}

A clean and healthy lifestyle (PHBS) is a set of behaviors that are practiced on the basis of awareness as a result of learning that makes a person, family, group or community able to help themselves (independently) in the health sector and play a role in realizing public health. The student group KKN BMC UNNES 2020 has a mission to make the people of Kalirancang Village, Alian District, Kebumen Regency, Central Java aware of implementing a clean and healthy lifestyle (PHBS) in their daily life, especially during the Covid-19 pandemic. The method of implementing KKN includes socialization and counseling on the application of a clean and healthy lifestyle (PHBS) directly to the people of Kalirancang Village, Alian District, which is the object. Several activities are carried out, such as weighing the baby every month, using clean water, washing hand use soap, healthy eating patterns, and doing bodily activities. The results achieved through these activities are being able to make people aware of the importance of implementing a clean and healthy lifestyle (PHBS) and can provide knowledge to the community regarding how to properly implement a clean and healthy lifestyle so that people can implement PHBS regularly in their daily life.

Keywords: clean and healthy lifestyle (PHBS), Kalirancang Village, socialization

\section{PENDAHULUAN}

Permasalahan kesehatan masyarakat Indonesia menjadi salah satu tantangan bukan hanya bagi pemerintah namun juga masyarakat itu sendiri. Bahkan dalam beberapa kasus, angka kematin cukup tinggi akibat dari tingginya angka penyakit di Indonesia, diantaranya Infeksi Saluran Pernapasan (ISPA), Tuberkulosis (TBC), dan Diare (Tahun 1990-an). Padahal, menurut Suryani, dkk (2019), pada tahun 2010, beberapa penyakit tidak menular seperti stroke, jantung, dan kencing manis justru memiliki proporsi fasilitas dan pelayanan kesehatan yang lebih besar. Namun, dewasa ini seluruh dunia tengah gempar akibat pandemi Coronavirus Disease 2019 (Covid19) termasuk di Indonesia. Penyakit Coronavirus Disease 2019 (COVID-19) adalah infeksi saluran pernapasan yang disebabkan oleh coronavirus yang baru muncul yang pertama dikenali muncul di Wuhan, Tiongkok, pada bulan Desember 2019. Pengurutan genetika virus ini 
mengindikasikan bahwa virus ini berjenis betacoronavirus yang terkait erat dengan virus SARS (World Health Organization, 2020). Penyakit ini dapat menular antar manusia hingga menyebabkan kematian. Oleh karena itu, pemerintah Indonesia menghimbau masyarakatnya untuk menerapkan pola hidup bersih dan sehat (PHBS) sebagai upaya pencegahan penularan Covid-19.

Simbolon \& Simorangkir (2018) menggarisbawahi bahwa pola hidup bersih dan sehat (PHBS) sebagai aktivitas dan perilaku yang dilaksanakan secara sadar dalam mendorong perilaku sehat bukan hanya bagi individual tetapi juga kelompok masyarakat, termasuk keluarga. Jenis-jenis PHBS bisa saja beragam mulai dari mencuci tangan menggunakan sabun, mengkonsumsi makanan dan minuman sehat, menggunakan jamban sehat, membuang sampah di tempat sampah, tidak merokok, tidak mengkonsumsi narkoba, alkohol, psikotropika dan zat aditif lainnya (NAPZA), tidak meludah sembarang tempat, memberantas jentik-jentik nyamuk.

Sementara itu, Septianto, dkk., (2020) dalam penelitiannya menyatakan bahwa pola hidup sehat didapat dari mereka yang memperhatikan keadaan tubuhnya, rajin berolahraga, makan, dan tidur yang cukup, sehingga hal tersebut akan menjadikan kualitas hidup seseorang meningkat. Sebaliknya, pola hidup tidak sehat didapat dari mereka yang tidak memperhatikan keadaan tubuhnya, makan yang tidak seimbang dengan aktivitasnya, dan jarang melakukan olahraga, sehingga hal tersebut akan menyebabkan sistem imun tubuh masyarakat terganggu.

Munasir (2016) menjelaskan bahwa sistem imun dari tiap individu berbeda-beda, namun demikian, sistem imun secara kolektif mampu didorong dengan berbagai perilaku hidup sehat. Sistem imun, menurutnya, merupakan sistem koordinasi respons biologik yang bertujuan melindungi integritas dan identitas individu serta mencegah invasi organisme dan zat yang berbahaya di lingkungan yang dapat merusak dirinya. Sistem imun mempunyai sedikitnya tiga fungsi utama, mulai dari kesanggupan untuk mengenal dan membedakan berbagai molekul target sasaran dan juga mempunyai respons yang spesifik, kesanggupan membedakan antara antigen diri dan antigen asing, hingga fungsi memori yaitu kesanggupan melalui pengalaman kontak sebelumnya dengan zat asing patogen untuk bereaksi lebih cepatdan lebih kuat daripada kontak pertama.

Namun demikian, tingkat pola hidup sehat di masyarakat masih rendah, terutama di Jawa Tengah. Data Laporan Rencana Strategis Dinas Kesehatan Provinsi Jawa Tengah Tahun 2018 sampai Tahun 2023 telah menggarisbawahi bahwa tingkat persentase Perilaku Hidup Bersih dan Sehat (PHBS) di Jawa Tengah sebesar 28\% (Kesehatan \& Jawa, 2012). Persentase tersebut menunjukkan tingkat kesadaran masyarakat Jawa Tengah untuk menerapkan pola hidup bersih dan sehat (PHBS) masih sangat rendah. Salah satu desa di provinsi Jawa Tengah yang masih mengabaikan pola hidup bersih dan sehat (PHBS) adalah desa Kalirancang. Kalirancang adalah desa yang terletak di Kecamatan Alian, Kabupaten Kebumen, Jawa Tengah. Di desa Kalirancang terlihat bahwa sebagian masyarakat yang menetap disana tidak menghiraukan masalah penerapan pola hidup bersih dan sehat. Berdasarkan data dari Pusat Informasi dan Koordinasi Covid-19 Pemerintah Kabupaten Kebumen bahwa angka kejadian pasien terkonfirmasi positif Covid-19 yang diperbarui pada hari Selasa, tanggal 1 September 2020 terdapat sebanyak 212 orang dengan rincian 41 orang dirawat, 158 orang sembuh, dan 6 orang meninggal dunia. Oleh karena itu, sangat penting menghimbau masyarakat Kebumen khususnya desa Kalirancang untuk menerapkan pola hidup bersih dan sehat (PHBS) dalam kehidupan sehari-hari.

Berdasarkan permasalahan di atas, maka penulis merumuskan artikel tentang bagaimana menerapkan pola hidup bersih dan sehat (PHBS) untuk masyarakat Desa Kalirancang di masa pandemi Covid-19.

\section{METODE}

A. Metode Pelaksanaan

Kegiatan ini dilaksanakan dengan menggunakan beberapa metode yakni sosialisasi, penyuluhan dan survey penerapan Pola Hidup Bersih dan Sehat (PHBS) secara langsung kepada masyarakat Desa Kalirancang Kecamatan Alian yang dijadikan obyek (50 orang masyarakat Desa).

\section{B. Waktu Pelaksanaan}

Program kegiatan sosialisasi dan penyuluhan Pola Hidup Bersih dan Sehat (PHBS) dilaksanakan sebanyak empat kali dengan setiap pertemuan satu jam setengah, yaitu: 
1. Tanggal 14 Juli 2020 dilaksanakan edukasi Pola Hidup Bersih dan Sehat (PHBS) kepada anak-anak masyarakat Desa Kalirancang melalui media edukasi poster.

2. Tanggal 17 Juli 2020 dilaksanakan kegiatan senam lansia.

3. Tanggal 21 Juli 2020 dilaksanakan edukasi Pola Hidup Bersih dan Sehat (PHBS) untuk ibu-ibu dan lansia di Desa Kalirancang.

4. Tanggal 16 Agustus 2020 dilaksanakan kegiatan sosialisasi dan penyuluhan Pola Hidup Bersih dan Sehat (PHBS). Kegiatan ini dilaksanakan di RT 2, RW 3, Dusun Kedungsemut Kulon, Desa Kalirancang, Kecamatan Alian, Kabupaten Kebumen.

\section{Jenis Penelitian}

Dalam pelaksanaan penelitian ini, peneliti menggunakan metode deskriptif kualitatif.

\section{Fokus Penelitian}

Penelitian ini difokuskan pada hal-hal sebagai berikut:

1. Perilaku hidup bersih dan sehat masyarakat Desa Kalirancang, Kecamatan Alian, Kabupaten Kebumen dalam meningkatkan kesehatan masyarakat, dengan indikator:

1) Aktivitas menimbang bayi setiap bulan

2) Penggunaan air bersih

3) Aktivitas mencuci tangan dengan air bersih dan sabun

4) Konsumsi buah dan sayur setiap hari

5) Intensitas melakukan aktivitas fisik

2. Beberapa faktor-faktor yang mungkin dapat mempengaruhi perilaku hidup bersih dan sehat di Desa Kalirancang, Kecamatan Alian, Kabupaten Kebumen, dengan indikator:

1) Tingkat pendidikan

2) Fasilitas Kesehatan

\section{E. Jenis dan Sumber Data}

Jenis dan sumber data yang digunakan dan disajikan dalam penelitian ini meliputi beberapa data, yakni:

1. Data primer, yaitu data yang diperoleh langsung oleh penulis dari lapangan (Desa Kalirancang Alian Kebumen), data ini meluputi dari hasil observasi, survey, dan wawancara secara langsung saat program dilaksanakan.
2. Data sekunder, yaitu data pendukung yang penulis dapatkan dari beberapa dokumen terkait, baik itu dokumen Desa Kalirancang, maupun dokumen lainnya yang tekait.

\section{HASIL DAN PEMBAHASAN \\ A. Penerapan Pola Hidup Bersih dan Sehat (PHBS)}

PHBS menurut Kementrian

Kesehatan merupakan kependekan dari Perilaku Hidup Bersih dan Sehat yang berarti perilaku kesehatan yang dilakukan karena kesadaran pribadi sehingga keluarga dan seluruh anggotanya mampu menolong diri sendiri pada bidang kesehatan serta memiliki peran aktif dalam aktivitas masyarakat.

Di masa pandemi ini, Perilaku Hidup Bersih dan Sehat pada dasarnya merupakan sebuah kebiasaan sederhana dengan upaya meningkatkan imun tubuh agar terhindar dari virus, baik untuk diri sendiri maupun orang lain disekitar kita.

Manfaat PHBS yang paling utama adalah terciptanya masyarakat yang sadar kesehatan dan memiliki bekal pengetahuan dan kesadaran untuk menjalani perilaku hidup yang menjaga kebersihan dan memenuhi standar kesehatan.

Pada pelaksanaan PHBS, ada beberapa pihak yang terlibat, dimana pihak tersebut merupakan bagian dari tempat beraktivitas dalam kehidupan sehari-hari. Berikut ini 6 proses penyadartahuan tentang perilaku hidup bersih sehat:

1. PHBS di Rumah tangga

2. PHBS di Sekolah

3. PHBS di Tempat kerja

4. PHBS di Sarana kesehatan

5. PHBS di Tempat umum

Manfaat PHBS secara umum adalah meningkatkan kesadaran masyarakat untuk mau menjalankan hidup bersih dan sehat. Hal tersebut agar masyarakat bisa mencegah dan menanggulangi masalah kesehatan. Selain itu, dengan menerapkan PHBS masyarakat mampu menciptakan lingkungan yang sehat dan meningkatkan kualitas hidup.

PHBS di sekolah merupakan kegiatan memberdayakan siswa, guru dan pola hidup sehat di masyarakat lingkungan sekolah. Tujuannya adalah supaya mau melakukan pola hidup sehat untuk menciptakan sekolah sehat. Manfaat PHBS di Sekolah mampu menciptakan lingkungan yang bersih dan sehat, serta pembelajaran yang nyaman dan sehat. 
$\begin{array}{cc}\text { Manfaat } & \text { PHBS di rumah tangga } \\ \text { antara lain, mampu meningkatkan }\end{array}$ kesejahteraan dan tidak mudah terkena penyakit, mampu meningkatkan produktivitas anggota rumah tangga dan menjadi terbiasa untuk menerapkan pola hidup sehat dan anak dapat tumbuh sehat dan tercukupi gizi.

PHBS di Tempat kerja adalah kegiatan untuk memberdayakan para pekerja agar tahu dan mau untuk melakukan Perilaku Hidup Bersih dan Sehat.

Manfaat PHBS di tempat kerja yaitu mampu meningkatkan imunitas tubuh, meningkatkan produktivitas kerja, dan meningkatkan citra tempat kerja yang positif.

Manfaat PHBS di masyarakat adalah masyarakat mampu menciptakan lingkungan yang sehat, mencegah penyebaran penyakit, dan mampu mengembangkan kesehatan yang bersumber dari masyarakat.

Pelaksanaan PHBS di lingkungan sekolah ditandai dengan beberapa aktivitas, yakni:

1. Mencuci tangan dengan sabun sebelum dan sesudah makan

2. Mengonsumsi jajanan sehat

3. Menggunakan jamban bersih dan sehat

4. Olahraga yang teratur

5. Memberantas jentik nyamuk

6. Tidak merokok di lingkungan sekolah

7. Membuang sampah pada tempatnya

8. Melakukan kerja bakti bersama warga lingkungan sekolah untuk menciptakan lingkungan yang sehat.

Selain itu, salah satu tatanan PHBS yang utama adalah PHBS rumah tangga yang bertujuan untuk mengedukasi anggota rumah tangga supaya mau melakukan perilaku di kehidupan sehari-hari, keluarga yang bersih nan sehat serta aktif di kehidupan masyarakat. Tujuan utama dari tatanan PHBS di tingkat rumah tangga adalah tercapainya rumah tangga yang sehat. Ini 10 indikator PHBS pada tingkatan rumah tangga:

1) Persalinan yang ditolong oleh tenaga kesehatan.

Persalinan yang mendapat pertolongan dari pihak tenaga kesehatan baik itu dokter, bidan ataupun paramedis memiliki standar dalam penggunaan peralatan yang bersih, steril dan juga aman. Langkah tersebut dapat mencegah infeksi dan bahaya lain yang beresiko bagi keselamatan ibu dan bayi yang dilahirkan.

2) Pemberian ASI eksklusif

Kesadaran mengenai pentingnya ASI bagi anak di usia 0 hingga 6 bulan menjadi bagian penting dari indikator keberhasilan praktek Perilaku Hidup Bersih dan Sehat pada tingkat rumah tangga.

3) Menimbang bayi dan balita secara berkala

Praktek tersebut dapat memudahkan pemantauan pertumbuhan bayi. Penimbangan dapat dilakukan di Posyandu sejak bayi berusia 1 bulan hingga 5 tahun. Posyandu dapat menjadi tempat memantau pertumbuhan anak dan menyediakan kelengkapan imunisasi. Penimbangan secara teratur juga dapat memudahkan deteksi dini kasus gizi buruk.

4) Cuci tangan dengan sabun dan air bersih

Praktek ini merupakan langkah yang berkaitan dengan kebersihan diri sekaligus langkah pencegahan penularan berbagai jenis penyakit berkat tangan yang bersih dan bebas dari kuman.

5) Menggunakan air bersih

Air bersih merupakan kebutuhan dasar untuk menjalani hidup sehat.

6) Menggunakan jamban sehat

Jamban merupakan infrastruktur sanitasi penting yang berkaitan dengan unit pembuangan kotoran dan air untuk keperluan pembersihan.

7) Memberantas jentik nyamuk Nyamuk merupakan vektor berbagai jenis penyakit dan memutus siklus hidup makhluk tersebut menjadi bagian penting dalam pencegahan berbagai penyakit.

8) Konsumsi buah dan sayur Buah dan sayur dapat memenuhi kebutuhan vitamin dan mineral serta serat yang dibutuhkan tubuh untuk tumbuh optimal dan sehat.

9) Melakukan aktivitas fisik setiap hari

Aktivitas fisik dapat berupa kegiatan olahraga ataupun aktivitas bekerja yang melibatkan gerakan dan keluarnya tenaga.

10) Tidak merokok di dalam rumah Perokok aktif dapat menjadi sumber berbagai penyakit dan masalah kesehatan bagi perokok pasif. Berhenti merokok atau setidaknya tidak merokok di dalam rumah dapat menghindarkan keluarga dari berbagai masalah kesehatan.

B. Implementasi Pola Hidup Bersih dan Sehat (PBHS) di Masa Pandemi Covid- 


\section{9 di Desa Kalirancang Alian Kebumen Jawa Tengah}

Corona Virus Disease (COVID-19) merupakan jenis penyakit baru yang sedang melanda di berbagai negara termasuk Indonesia. Pada manusia biasanya menyebabkan infeksi saluran pernapasan, mulai flu biasa sampai penyakit yang serius seperti Middle East Respiratory Syndrome (MERS) dan Sindrom Pernafasan Akut Berat/Severe Acute Respiratory Syndrome (SARS). Coronavirus jenis baru muncul di Wuhan, China pada Desember 2019, kemudian diberi nama Severe Acute Respiratory Syndrome Coronavirus 2 (SARSCOV2), dan menyebabkan penyakit Coronavirus Disease-2019 (COVID-19). (Kemkes RI, 2020).

Virus covid-19 telah menyebar di berbagai belahan dunia, bukan hanya negara, provinsi, kabupaten, tetapi ke daerah-daerah pelosok desa yang menimbulkan kekhawatiran warga selama ini. Gelaja klinis yang ditimbulkan antara lain demam; batuk, pilek; letih, lesu; sakit tenggorokan, dan gangguan (sesak) pernapasan. Penyebaran virus ini tergolong sangat cepat, bisa melalui droplets atau tetesan cairan yang berasal dari batuk dan bersin, kontak pribadi seperti menyentuh dan berjabat tangan, dan menyentuh benda atau permukaan dengan virus di atasnya, kemudian menyentuh mulut, hidung atau mata sebelum mencuci tangan. Untuk mengurangi risiko penyebaran virus covid-19 pemerintah telah mengambil kebijakan antara lain Pembatasan Sosial Berskala Besar (PSBB) yang telah diterapkan dibeberapa kota besar yang memasuki zona merah di Indonesia.

Kondisi pandemi covid-19 pada akhirnya membuat masyarakat untuk menerapkan pola hidup bersih dan sehat menjadi rutinitas. Hal ini dikarenakan penyebaran covid-19 yang semakin meluas dan saat ini belum tersedia vaksin covid-19. Beberapa hal yang bisa dilakukan masyarakat untuk mencegah penularan yaitu dengan mencuci tangan setiap 1-2 jam dengan cara yang benar. Selain itu, melakukan aktivitas fisik seperti berolahraga secara rutin di dalam atau sekitar rumah.
Serta, mengkonsumsi makanan sehat dan seimbang yang mengandung berbagai vitamin untuk daya tahan tubuh (Anhusadar dan Islamiyah, 2020).

Pola hidup bersih dan sehat merupaka hal yang sangat penting bagi kelangsungan hidup seluruh anggota keluarga. Didalam PHBS rumah tangga terdapat 10 indikator. Berdasarkan observasi yang telah dilakukan sebelumnya maka digunakan 5 indikator pola hidup bersih dan sehat (PHBS) pada sosialisasi di Dusun Kedungsemut kulon dan Dusun Jerotengah. Indikator pola hidup bersih dan sehat yang digunakan yaitu menimbang bayi dan balita, menggunakan air bersih, mencuci tangan dengan air bersih dan sabun, makan buah dan sayur setiap hari, dan melakukan aktivitas tubuh. Pemilihan lima indikator ini dikarenakan permasalahan yang ditemukan pada saat observasi di dua dusun tersebut dan menyesuaikan dengan kondisi sekarang yaitu adanya wabah pandemi covid-19.

Kegiatan sosialisasi pola hidup bersih dan sehat (PHBS) di Dusun Kedungsemut kulon dan Dusun Jerotengah dalam meningkatkan kesehatan dan mencegah penularan covid-19.

a. Menimbang Bayi dan Balita

Desa Kalirancang memiliki kegiatan penimbangan di Pos Pelayanan Terpadu (Posyandu) yang dilaksanakan setiap satu bulan sekali di hari Sabtu minggu pertama. Kegiatan Posyandu ini dilaksanakan di tempat Polindes yang berada di dekat TK PERTIWI dan berseberangan dengan balai desa Desa Kalirancang. Ada kurang lebih 16 balita yang terdaftar mengikuti kegiatan posyandu ini terkait pemantauan kesehatan anak sejak usia 0 bulan hingga 5 tahun. Tentunya pihak desa mendukung kegiatan yang dilaksanakan oleh kader-kader desa dalam meningkatkan kesehatan anak-anak di tingkat desa.

Tahun 2020 ini terdapat satu bidan dan dibantu enam kader. Bulan Juli lalu, balita mendapatkan vitamin A dari puskesmas. Pemberiannya ada yang diminum ditempat ada pula yang dibawa pulang. Pemberian vitamin A ini diberikan dua kali dalam satu tahun. Diharapkan sejak dini balita dapat mencegah kerusakan pada organ mata. 
Tabel 1. Daftar nama peserta balita di Posyandu “Kenanga II" Desa Kalirancang (Data Per 5/9/2020)

\begin{tabular}{|c|c|c|c|c|c|c|c|}
\hline No. & Nama Lengkap & $\begin{array}{c}\text { Tanggal } \\
\text { Lahir } \\
\text { (TGL/BLN } / T \\
\text { HN) }\end{array}$ & $\begin{array}{c}\text { Jeni } \\
\text { s } \\
\text { (P/L) }\end{array}$ & Nama Ibu & Nama Ayah & $\begin{array}{l}\text { BB } \\
\text { (KG) }\end{array}$ & $\begin{array}{l}\text { TB } \\
\text { (CM) }\end{array}$ \\
\hline 1 & Abrizam Fahrazi W. & $12 / 3 / 2020$ & $\mathrm{~L}$ & Endah Lestari & Muhamad Fauji & 12.3 & 78 \\
\hline 2 & Adian Arwan Singgih & $30 / 7 / 2019$ & L & Nur Aeni & Hermanto & 10.5 & 75 \\
\hline 3 & Ahmad Fajri & $9 / 7 / 2017$ & L & Sri Maryati & Kasikun & 11.1 & 86 \\
\hline 4 & Aisyah Nur Azzahra & $3 / 5 / 2018$ & $P$ & Khotijah & Sumarsono & 10 & 83 \\
\hline 5 & Arfan Rais Nur Fatih & $6 / 6 / 2020$ & L & $\begin{array}{l}\text { Siti Nur } \\
\text { Hamidah }\end{array}$ & Muhamad Ocim & 5.1 & 57 \\
\hline 6 & Ayunindia & $29 / 11 / 2016$ & $P$ & $\begin{array}{l}\text { Siti Nur } \\
\text { Hamidah }\end{array}$ & Ade Widiawan & 13 & 91 \\
\hline 7 & Azqa Aqila S. & 9/9/2019 & $P$ & Nur Awaliyah & Nurul Hidayat & 7.6 & 68 \\
\hline 8 & $\begin{array}{l}\text { Defano Ahmad Al } \\
\text { Fikri }\end{array}$ & $19 / 8 / 2016$ & L & Rochyani & Darmadi & 15.6 & 104 \\
\hline 9 & Faiqah Melani Putri & $17 / 3 / 2017$ & $P$ & Ropiku & $\begin{array}{l}\text { Mohamad } \\
\text { Solihun }\end{array}$ & 12.3 & 93 \\
\hline 10 & $\begin{array}{l}\text { Faishal Imamul } \\
\text { Hakim }\end{array}$ & $5 / 2 / 2019$ & L & Sri Karyati & Ngatiman & 10.6 & 74 \\
\hline 11 & Farzana Naina A. & $23 / 7 / 2020$ & $P$ & Khotijah & Sumarsono & 4.1 & 3.5 \\
\hline 12 & $\begin{array}{l}\text { Fatian Ghaisan } \\
\text { Munir }\end{array}$ & $1 / 1 / 2017$ & L & Siti Muzakiyah & Riski Misbahu & 14.6 & 95 \\
\hline 13 & Fayra Khairina A. & 19/08/2016 & $P$ & $\begin{array}{l}\text { Silvi Widia } \\
\text { Rahma }\end{array}$ & $\begin{array}{l}\text { Slamet } \\
\text { Saefudin }\end{array}$ & 13.3 & 87 \\
\hline 14 & $\begin{array}{l}\text { Kafa Nikmatul } \\
\text { Fadilah }\end{array}$ & $15 / 11 / 2017$ & $P$ & Istiqomah & Darmadi & 12 & 90 \\
\hline 15 & Kahisha Safwana P. & $9 / 6 / 2020$ & $P$ & Ade Roswita & Edi Purwanto & 6.1 & 57 \\
\hline 16 & Khalila Zelindra KJ. & $30 / 9 / 2015$ & $P$ & Jumiah & Satino & 13.7 & 94 \\
\hline 17 & Maryam Covana M. & $16 / 3 / 2016$ & $P$ & Rahmayani & Muhydin & 12.6 & 90 \\
\hline 18 & Raisa Hasna Hanifa & $31 / 3 / 2017$ & $P$ & $\begin{array}{l}\text { Esti } \\
\text { Purwaningsih }\end{array}$ & $\begin{array}{l}\text { Ahmas } \\
\text { Saefudin M. }\end{array}$ & 14 & 97 \\
\hline
\end{tabular}

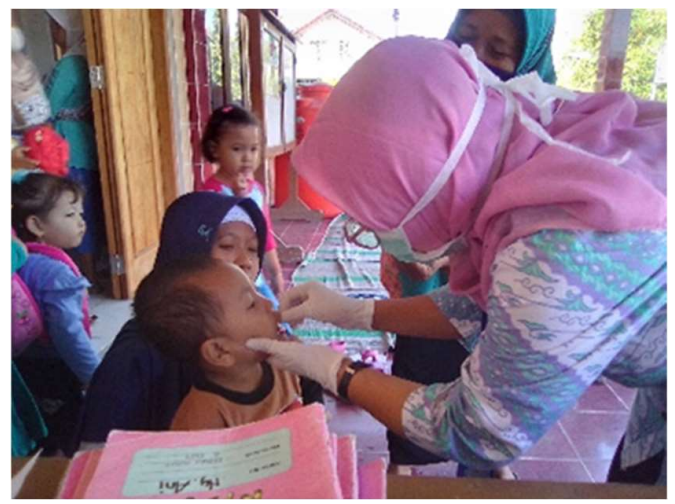

Gambar 1. Pemberian Vitamin A pada Balita

Selain itu, kegiatan posyandu ini memiliki target dalam peningkatan kesehatan balita. Beberapa hal yang harus dicek adalah berat badan dan tinggi badan atau panjang badan. Selain di masa pandemi, akan ada game dari para kader untuk menambah wawasan mereka. Mulai dari menyanyi hingga hafalan doa-doa bersama. Posyandu juga menyediakan mainan untuk balita supaya peka terhadap segala hal. Pendemi yang masih ada ini, kegiatan posyandu hanya pengecekan utama kemudian diberi PMT, setelah itu pulang. Tentu saja protokol kesehatan sangat diutamakan. Walaupun pandemi masih ada, tetapi di sinilah waktu yang tepat untuk semakin mempererat pemantauan kesehatan pada balita. Karena balita juga merupakan usia yang rentan akan virus. Kemenkes tentu sangat memperhatikan hal demikian, hampir 5 bulan posyandu tidak berjalan, kini dengan tetap patuhi protokol kesehatan, posyandu kembali dilaksanakan dengan catatan tidak ada kerumunan seperti biasanya. Data perkembangan peserta Posyandu dapat dilihat pada Tabel 1. 


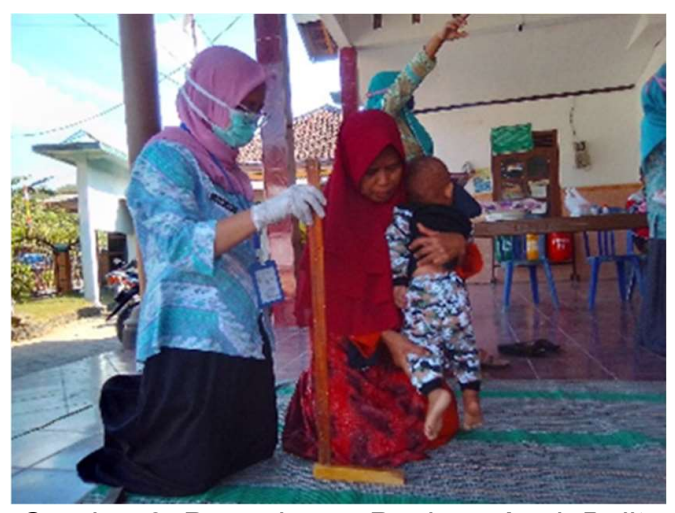

Gambar 2. Pengukuran Panjang Anak Balita

b. Mengunakan air bersih

Masyarakat di Dusun Kedungsemut Kulon dan Dusun jerotengah mendapatkan air bersih dari air sumur maupun PAM. Kebutuhan air bersih ini dipergunakan seharihari untuk minum, memasak, mandi, mencuci pakaian, mencuci peralatan dapur, dan sebagainya. Manfaat menggunakan air bersih dapat terhindari dari gangguan penyakit seperti diare, kolera, disentri, typus, kecacingan, dan lain-lain.

Penggunaan air bersih harus dimasak sampai mendidih bila ingin diminum. Hal ini dikarenakan, air yang terlihat bersih, belum tentu terbebas dari kuman. Kuman penyakit dalam air mati pada suhu 100 derajat celcius (saat mendidih). Selain itu, informasi yang diberikan saat sosialisasi apabila sumber air bersih tidak mematuhi persyaratan air bersih secara fisik, salah satu anggota keluarga diharapkan melapor ke puskesmas untuk mendapat tindak lanjut. Syarat air bersih secara fisik itu dapat dibedakan melalui indera antara lain dapat dilihat, dirasa, dicium dan diraba. Misalkan, air tidak keruh, harus bebas dari pasir, debu, lumpur, sampah, busa dan kotoran lainnya.

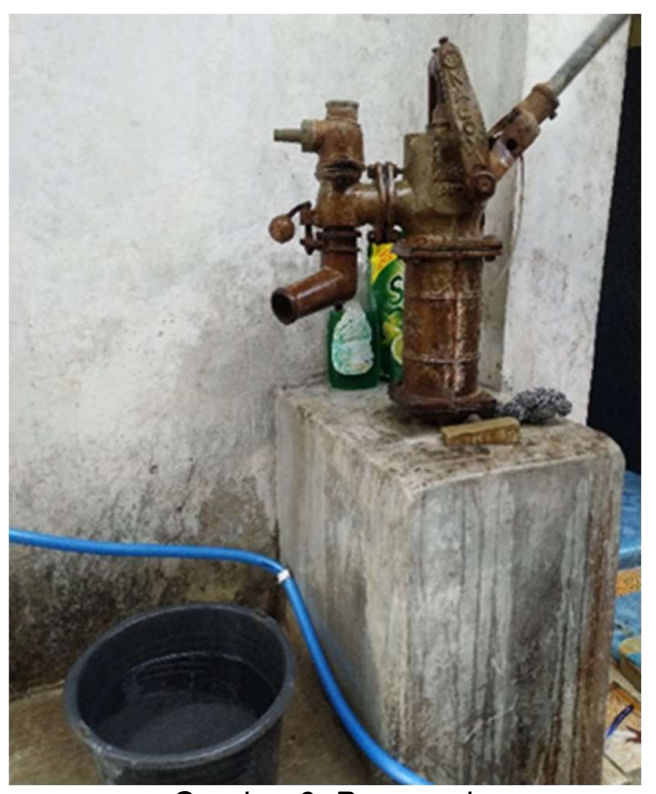

Gambar 3. Pompa air

c. Mencuci tangan dengan air bersih dan sabun

Masyarakat melakukan cuci tangan setelah menyeboki bayi atau anak, sesudah berkebun, sebelum makan dan minum dan sesudah buang air bersih. Kebiasaan mencuci tangan menggunakan air saja tidak dapat melindungi dari bakteri dan virus. Terlebih jika cuci tangan tidak di bawah air mengalir. Kebiasaan ini harus segera ditinggalkan dan dirubah menjadi yang lebih baik dengan standar prosedur melakukan cuci tangan menggunakan sabun.

Cara cuci tangan pakai sabun yang benar adalah menggosok telapak tangan secara bersamaan, mengosok punggung kedua tangan, jalinkan kedua telapak tangan lalu digosok-gosokan, tautakn jari-jari antara kedua telapak tangan secara berlawanan, gosok ibu jari secara memutar dilanjutkan dengan daerah antara jari telunjuk dan ibu jari secara bergantian, gosok kedua pergelangan tangan dengan arah memutar, bilas dengan air dan keringkan. (Kemenkes RI, 2014) 


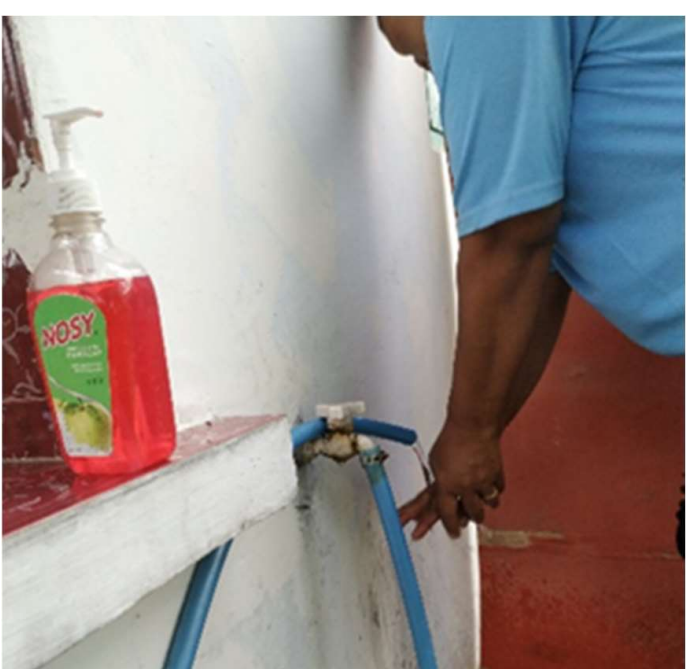

Gambar 4. Mencuci tangan dengan air mengalir dan sabun

Menggunakan sabun dalam cuci tangan diketahui sebagai salah satu upaya pencegahan penyakit. Hal ini dikarenakan tangan merupakan agen yang membawa kuman dan menyebabkan patogen yang berpindah dari satu orang ke orang lain melalui kontak langsung maupun tidak langsung. (Anhusadar dan Islamiyah, 2020)

Pada masa pandemi, kebiasan cuci tangan sebaiknya dilakukan setiap 1-2 jam sekali. Hal ini untuk mencegah penularan covid-19. Selain itu, masyarakat juga menyediakan kran atau penampung air didepan rumah dilengkapi dengan sabun untuk setiap tamu yang berkunjung kerumah harus mencuci tangan terlebih dahulu.

\section{d. Makan sayur dan buah setiap hari}

Makan sayur dan buah setiap hari sangat penting. Hal ini dikarenakan mengandung vitamin dan mineral yang mengatur metabolisme energi, pertumbuhan, dan pemeliharaan tubuh. Selain itu sayur mengandung serat yang tinggi yang berguna untuk memelihara usus.

Setiap anggota keluarga diharapkan mengkonsumsi 3 porsi buah dan 2 porsi sayuran atau sebaliknya setiap hari. Cara mengolah sayur cukup penting supaya vitamin dan mineral tetap ada, lebih baik sayuran dimakan segar atau dikukus, karena jika direbus cenderung melarutkan vitamin dan mineral.

Di masa pandemi, mengonsumi sayur dan buah harus ditingkatkan untuk menjaga imunitas tubuh. Pada anak-anak dibawah 5 tahun dan orang dewasa lebih dari 65 tahun tergolong rentan terhadap penyakit covid- 19 .

e. Melakukan aktivitas fisik

Pandemi ini semua usia herus mnyerah dan segera untuk cuci tangan. Selain balita, usia lansia juga harus diperhatikan untuk dalam pemantauan kesehatan. Pelaksanaan darurat ini ialah seperti melalui cek suhu, berat badan, tes cek darah.

Senam lansia dilakukan sebulan sekali di minggu ketiga di hari Jum'at. Selain lansia, ibu-ibu juga dibolehkan untuk ikut senam. Kegiatan ini juga ada seperti PMT, beragam dari setiapa bulannya. Pemimpin senam/ struktur yaitu dari anggota kader desa sendiri.

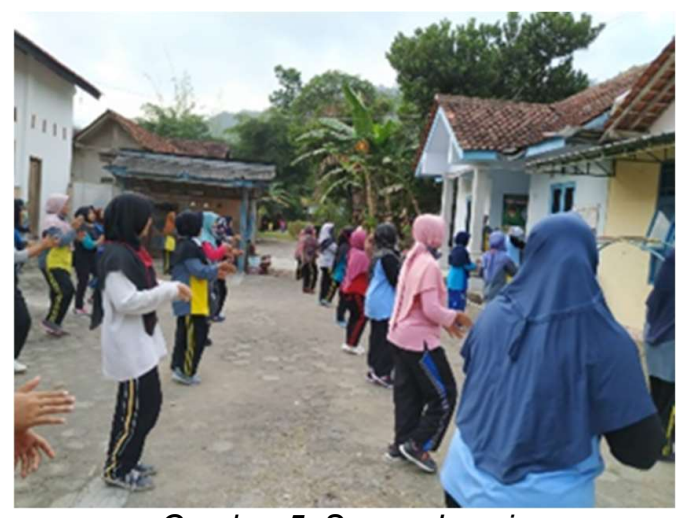

Gambar 5. Senam Lansia

Faktor-faktor yang mempengaruhi tingkat perilaku hidup bersih dan sehat menurut penelitian Desi yaitu tingkat pengetahuan dan sikap masyarakat. Selain itu, menurut penelitian Gita faktor yang mempengaruhi pola hidup bersih dan sehat yaitu faktor usia dan pengetahuan.

Menurut Lawrence Green, faktorfaktor yang mempengaruhi perilaku hidup bersih dan sehat dibagi menjadi 3 bagian yaitu faktor predisposisi (umur, tingkat pengetahuan masyarakat), faktor pemungkin (fasilitas dan sarana) dan faktor penguat (dukungan tokoh masyarakat, perilaku petugas kesehatan, dan tersampaikan atau tidaknya promosi kesehatan PHBS terhadap masyarakat tersebut) (Green, 2005).

\section{Perubahan Pola Hidup Masyarakat Desa Kalirancang Kebumen Jawa Tengah}

Program yang dilaksanakan oleh tim merupakan salah satu program dalam KKN Bersama Melawan Covid (BMC) yang 
ditujukan untuk mendorong pola hidup bersih dan sehat masyarakat desa di masa pandemi covid-19. Melalui program ini, ada perubahan yang signifikan yang ditunjukkan oleh masyarat Desa Kalirancang Kecamatan Alian, Kabupaten Kebumen Jawa Tengah dalam menerapkan pola hidup bersih dan sehat (PBHS).

Perubahan pola tersebut, secara nyata dapat dilihat dari hasil analisis terhadap aktivitas sebelum dan setelah program dilaksanakan, dimana aktivitas tersebut melibatkan masyarakat Desa Kalirancang Kecamatan Alian, Kabupaten Kebumen Jawa Tengah, dimana survei melibatkan 50 orang masyarakat desa, seperti ditunjukkan pada Tabel 2.

Tabel 2. Prosentase Perubahan Pola Hidup Masyarakat Desa Kalirancang (sebelum dan setelah program)

\begin{tabular}{|c|c|c|c|c|c|}
\hline \multirow{3}{*}{ No } & \multirow{3}{*}{ Indikator Pola Hidup Bersih dan Sehat } & \multicolumn{4}{|c|}{ Prosentase (\%) } \\
\hline & & \multicolumn{2}{|c|}{ Sebelum } & \multicolumn{2}{|c|}{ Setelah } \\
\hline & & $\mathrm{S}$ & $\mathrm{B}$ & $\mathrm{S}$ & $\mathrm{B}$ \\
\hline 1 & $\begin{array}{l}\text { Apakah Bayi, Balita, Anak Anda secara rutin ditimbang } \\
\text { dan dipantau ke Posyandu Desa? }\end{array}$ & 16 & 84 & 95 & 5 \\
\hline 2 & $\begin{array}{l}\text { Apakah secara rutin memantau pertumbuhan anak dan } \\
\text { gizi anak di Posyandu? }\end{array}$ & 15 & 85 & 95 & 5 \\
\hline 3 & Apakah secara rutin anak diberikan susu? & 13 & 87 & 95 & 5 \\
\hline 4 & Apakah di rumah menggunakan air bersih? & 40 & 60 & 90 & 10 \\
\hline 5 & $\begin{array}{l}\text { Apakah air minum di rumah menggunakan air tanah yang } \\
\text { dimasak? }\end{array}$ & 22 & 78 & 85 & 15 \\
\hline 6 & $\begin{array}{l}\text { Apakah di rumah terdapat fasilitas mencuci tangan yang } \\
\text { mengalir? }\end{array}$ & 23 & 77 & 80 & 20 \\
\hline 7 & $\begin{array}{l}\text { Apakah secara rutin selalu mencuci tangan sebelum } \\
\text { makan? }\end{array}$ & 25 & 75 & 100 & 0 \\
\hline 8 & $\begin{array}{l}\text { Apakah secara rutin membersihkan rumah menggunakan } \\
\text { cairan disinfektan/pembunuh kuman? }\end{array}$ & 4 & 96 & 85 & 15 \\
\hline 9 & $\begin{array}{l}\text { Apakah secara rutin pakaian dibersihkan menggunakan } \\
\text { cairan khusus? }\end{array}$ & 69 & 31 & 100 & 0 \\
\hline 10 & $\begin{array}{l}\text { Apakah setiap hari keluarga sudah memakan sayuran } \\
\text { secara seimbang? }\end{array}$ & 13 & 87 & 91 & 9 \\
\hline 11 & $\begin{array}{l}\text { Apakah setiap hari sudah mengkonsumsi buah-buahan } \\
\text { secara seimbang? }\end{array}$ & 12 & 88 & 92 & 8 \\
\hline 12 & $\begin{array}{l}\text { Apakah setiap hari sudah melakukan aktivitas fisik/ } \\
\text { senam kesehatan? }\end{array}$ & 3 & 97 & 85 & 15 \\
\hline 13 & Apakah secara rutin anda menguras bak mandi? & 4 & 96 & 85 & 15 \\
\hline 14 & Apakah secara rutin anda menerapkan $3 \mathrm{M}$ ? & 7 & 93 & 100 & 0 \\
\hline 15 & $\begin{array}{l}\text { Apakah anda sudah mengetahui apa itu Pola Hidup } \\
\text { Bersih dan Sehat (PBHS)? }\end{array}$ & 7 & 93 & 100 & 0 \\
\hline
\end{tabular}

Keterangan:

S : Sudah melakukan

B : Belum melakukan

\section{PENUTUP}

\section{Simpulan}

Program ini menyimpulkan bahwa dorongan atas pola hidup bersih dan sehat bisa dipengaruhi oleh beberapa hal, diantaranya: (1) tingkat pemahaman/edukasi masyakarakat, (2) dukungan sarana/fasilitas, dan (3) kultur masyarakat. Di Desa Kalirancang Alian Kebumen, menunjukkan perubahan pola hidup yang signifikan dari sebelum dan setelah program dilaksanakan. Dimana secara umum, perilaku pola hidup bersih dan sehat warga meningkat secara signifikan. Hal tersebut ditunjukkan dengan peningkatan prosentasi item pola hidup bersih dan sehat, mulai dari penggunaan air bersih, konsumsi sayuran dan buah-buahan, mengecek pertumbuhan anak di posyandu, 
hingga intensitas melakukan aktivitas fisiki dan senam kesehatan.

\section{Saran}

Penerapan pola hidup bersih dan sehat ini perlu dipantau oleh pihak desa. Hal ini bisa dibantu oleh kader-kader desa untuk gencar melakukan sosialisasi terkait penerapan pola hidup sehat dalam rumah tangga. Diharapkan 10 indikator ber-PHBS dalam rumah tangga bisa diterapkan pada masing-masing kepala keluarga di Desa Kalirancang. Sehingga anggota keluarga sehat dan tidak mudah sakit.

\section{DAFTAR PUSTAKA}

Anhusadar, La Ode dan Islamiyah. 2020. Penerapan Perilaku Hidup Bersih dan Sehat Anak Usia Dini di Tengah Pandemi Covid 19. Jurnal Obsesi: Jurnal Pendidikan Anak Usia Dini. $5(1): 467-468$

Green, W, Lawrence. et.al. 2005. Health Education Planing A Diagnostik Approach, The Johns Hapkins University. Mayfield Publishing Company

http://promkes.kemkes.go.id/phbs\#: :text=PH BS\%20merupakan\%20kependekan\%2 Odari\%20Perilaku,peran\%20aktif\%20d alam\%20aktivitas \%20masyarakat

https://covid19.kemkes.go.id/situasi-infeksiemerging/info-corona-virus/tanyajawab-coronavirus-disease-covid-19qna-update-6-maret-2020/

Kemenkes RI. 2014. Profil Kesehatan Indonesia. Jakarta: Kemenkes

Kesehatan, D., \& Jawa, P. (2012). Dinas
Kesehatan Provinsi Jawa Tengah. 3511351(24).

Munasir, Z. (2016). Respons Imun Terhadap Infeksi Bakteri. Sari Pediatri, 2(4), 193. https://doi.org/10.14238/sp2.4.2001.193 $-7$

Prihanti, Gita Sekar, et al. 2018. FaktorFaktor yang Mempengaruhi Tingkat Perilaku Hidup Bersih dan Sehat pada Tatanan Rumah Tangga di Wilayah Kerja Puskesmas Poned X. Jurnal Saintika Medika. 14(1):11

Septianto, A., Nurmutia, S., Feblidiyanti, N., \& Pamulang, U. (2020). Sosialisasi pentingnya pola hidup sehat guna meningkatkan kesehatan tubuh pada masyarakat desa kalitorong kecamatan randudongkal kabupaten pemalang provinsi jawa tengah. 1(2), 55-62.

Simbolon, P., \& Simorangkir, L. (2018). Penerapan UKS dengan PHBS di Wilayah Kerja Puskesmas Pancur Batu Kabupaten Deli Serdang. Jurnal Kesehatan Lingkungan Indonesia, 17(1), 16. https://doi.org/10.14710/jkli.17.1.16-25

Suryani, D., Nurdjanah, E. P., Yogatama, Y., \& Jumadil, M. (2019). Membudayakan Hidup Sehat Melalui Gerakan Masyarakat Hidup Sehat (Germas) Di Dusun Mendang lii, Jambu Dan Jrakah Kecamatan, Tanjungsari, Gunungkidul. Jurnal Pemberdayaan: Publikasi Hasil Pengabdian Kepada Masyarakat, 2(1), 65. https://doi.org/10.12928/jp.v2i1.486

World Health Organization. (2020). Tatalaksana klinis infeksi saluran pernapasan akut berat ( SARI ) suspek penyakit COVID-19. World Health Organization, 4(March), 1-25. 